\title{
PEMANFAATAN LIMBAH PLASTIK MENJADI BARANG BERNILAI EKONOMI UNTUK MENINGKATKAN PENDAPATAN MASYARAKAT DI DESA TANJUNG REJO PERCUT SEI TUAN
}

\author{
Sari Wulandari ${ }^{1)}$, Dewi Nurmala ${ }^{2)}$, Ratna Sari Dewi ${ }^{3)}$ \\ Universitas Muslim Nusantara Al-Washliyah ${ }^{1)}$ \\ Universitas Muslim Nusantara Al-Washliyah ${ }^{2)}$ \\ Universitas Muslim Nusantara Al-Washliyah ${ }^{3)}$ \\ sariwulandari@umnaw.ac.id \\ dewinurmala@umnaw.ac.id \\ rsdewilubis@umnaw.ac.id
}

\begin{abstract}
ABSTRAK
Pengabdian pada Masyarakat ini bertujuan untuk memberikan wawasan pengetahuan mengenai berkarya dengan mengolah limbah plastik menjadi barang yang bernilai ekonomi sehingga dapat menambah pendapatan pada masyarakat yang ada di Desa Tanjung Rejo Kecamatan Percut Sei Tuan kabupaten Deli Serdang dengan memberikan wawasan pentingnya menjaga lingkungan di sekitar. Sasaran pengabdian adalah masyarakat di Desa Tanjung Rejo Kecamatan Percut Sei Tuan Kabupaten Deli Serdang. Permasalahan diselesaikan dalam tiga tahapan Perencanaan, Pelaksanaan dan Evaluasi. Perencanaan dilakukan dengan cara melakukan survey dan melihat kondisi dilapangan. Pelaksanaan dilakukan dengan pelatihan yang dilakukan dengan metode ceramah dan praktek langsung pengolahan limbah tutup botol plastik. Evaluasi kegiatan dilakukan dengan melihat hasil karya inovasi yang telah dilakukan masyarakat. Hasil Kegiatan pelatihan menunjukkan tanggapan yang sangat baik dari masyarakat dengan adanya respon yang positif dari masyarakat dilihat dari inovasi yang mereka hasilkan atas pengolahan limbah plastik tersebut.
\end{abstract}

Kata kunci : limbah plastik, pendapatan, lingkungan

This community service aims to provide insight into knowledge about processing plastic waste into goods of economic value so that it can increase income for the people in Tanjung Rejo, Percut Sei Tuan, Deli Serdang Regency by providing insight into the importance of the surrounding environment. The target of community service is the community in Tanjung Rejo, Percut Sei Tuan, Deli Serdang Regency. Basic problems in three stages of Planning, Implementation and Evaluation. Planning is done by conducting surveys and seeing conditions in the field. The implementation is carried out with training conducted with the lecture method and practice of processing plastic bottle cap waste. Evaluation of activities is carried out by looking at the results of innovation work that has been carried out by the community. The results of the training activities show a very good response from the community with a positive response from the community seen from the innovations they produce for processing this plastic.

Keywords: plastic waste, environment

\section{PENDAHULUAN}

Desa Percut Sei Tuan merupakan sebuah desa yang terletak dipesisir, dimana Lapangan pekerjaan masyarakat disana mayoritas sebagai nelayan dan buruh tani dimana pemilik lahan berasal dari kota Medan.

Seiring dengan perkembangan zaman dan meningkatkan barang-barang pemuas kebutuhan maka pekerjaan mereka tersebut belum tentu dapat memenuhi keperluan sehari-hari, apalagi di era globalisasi seperti sekarang ini.

Perkembangan zaman yang memacu pada peningkatan Ilmu Pengetahuan dan Teknologi (IPTEK) membuat mayasrakat mau tidak mau untuk mengikuti keadaan, dimana barang pemuas kebutuhan yang semakin menipis namun konsumsi masyarakat terus meningkat.

Semakin meningkatkan barang pemuas kebutuhan maka semakin banyak 
pula sampah. Sampah tersebut diantara adalah kemasan botol plastik. Botol plastik merupakan salah satu limbah yang cukup berbahaya karena tidak semua botol plastik dapat terurai.

Botol plastik dapat ditemukan dimana saja, terutama di sekitar lingkungan masyarakat. Botol-botol tersebut terbuang sia-sia padahal masih bisa diberdayakan bahkan bisa menjadi pendapatan tambahan bagi masyarakat apabila mereka mampu mengolahnya dengan sebaik mungkin.

Untuk itu Universitas Muslim Nusantara Al Washliyah melalui Fakultas Ekonomi berusaha menjadi media untuk memberikan penyuluhan pengolahan sampah plastic kepada masyarakat melalui program pengabdian masyarakat. Kegiatan ini diharapkan mampu untuk meningkatkan kualitas masyarakat dalam mengolah sampah plastic menjadi suatu barang yang bernilai ekonomi sehingga dapat menambah penghasilan dan menaikkan taraf ekonomi masyarakat.

\section{METODE PELAKSANAAN}

Untuk memberikan hasil yang maksimal dari semua yang telah direncanakan sebelumnya, maka akan dilakukan beberapa kegiatan diantara memberikan informasi mengenai sampah sampah plastic yang bisa digunakan dan berbagai cara pengolahan sampah plastic.

Program kegiatan ini menggunakan alat-alat bantu yang beberapa diantaranya adalah peralatan rumah tangga seperti gunting, lem tembak dan kabel ties. Alatalat bantu tersebut sangat mudah didapat dan harganya tidak mahal.

Dalam menyelesaikan permasalahan mitra ada beberapa program yang dapat dilaksanakan untuk memenuhi kebutuhan masyarakat dalam meningkatkan kemampuan dalam berkreativitas yaitu dengan cara:

a. Menayangkan beberapa film pendek mengenai bagaimana cara mengolah botol ataupun tutup botol palstik. b. Memperaktikkan apa yang telah ditonton sehingga bisa diatasi dimana letak ketidak mampuan masyarakat untuk mengolah barang tersebut sehingga didapatlah solusinya.

\section{HASIL DAN PEMBAHASAN}

Hasil yang sudah dicapai dalam Pengabdian Masyarakat berbasis Ipteks bagi Masyarakat (IbM) adalah:

1. Bersosialisasi dengan masyarakat terutama ibu-ibu dengan memberikan pelatihan pengolahan sampah plastik khususnya pengolahan tutup botol menjadi barang-barang bernilai guna.

Pelatihan dilaksanakan di Balai Desa Tanjung Rejo dengan fasilitas ruangan, infokus, mic dan sound system yang dianggap sudah memenuhi syarat dalam melaksanakan pelatihan.

2. Penyiapan Peralatan dan Pelaksanaan Pelatihan

Sesuai dengan koordinasi, tim pelaksana menyiapkan alat dan bahan untuk keperluan pelatihan berupa sampah tutup botol plastik dengan berbagai jenis, kabel ties, lem tembak dan penyiapan materi. Materi yang diberikan berupa power point langkah-langkah pengerjaan pembuatan tutup botol menjadi tempat sampah.

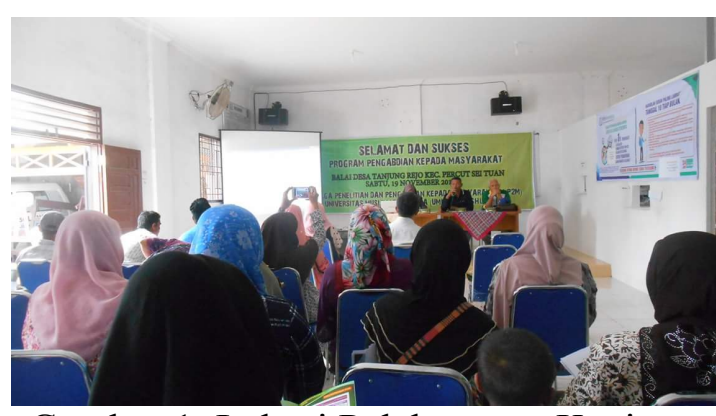

Gambar 1. Lokasi Pelaksanaan Kegiatan $\mathrm{IbM}$ 


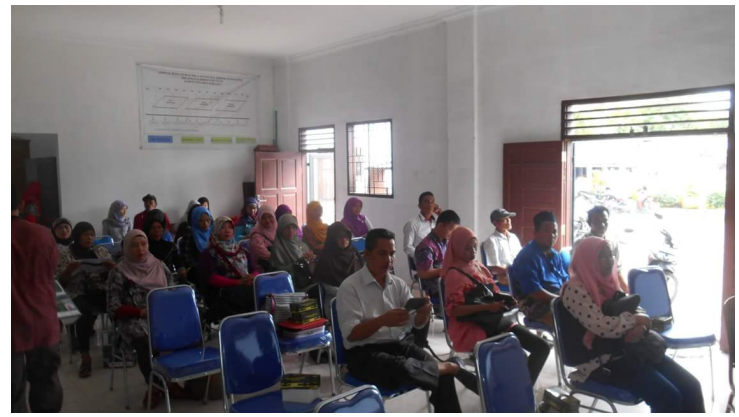

Gambar 2. Suasana Pelaksanaan Kegiatan $\mathrm{IbM}$

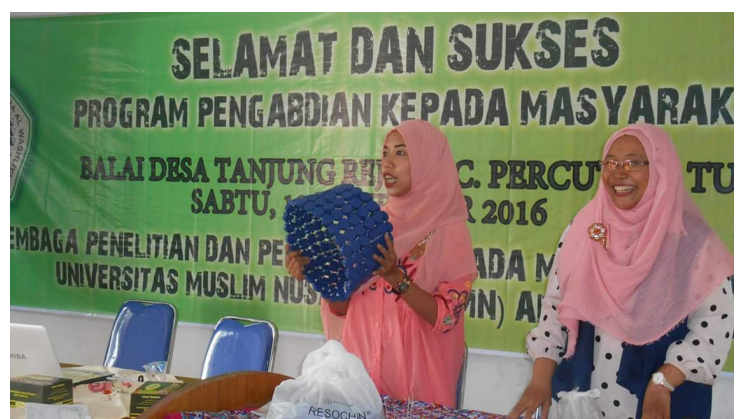

Gambar 3. Gambar Tim sedang melakukan tutor

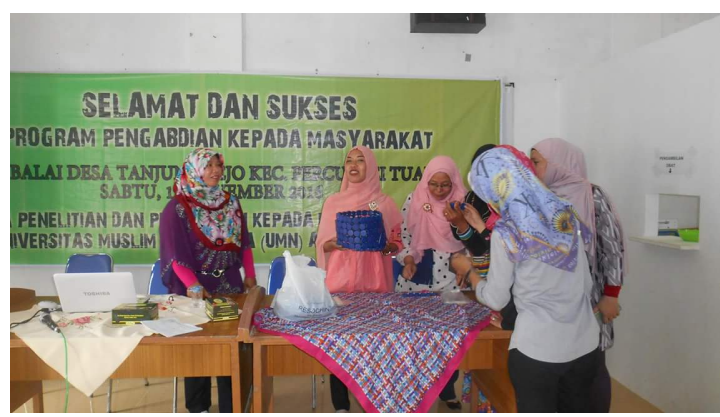

Gambar 4. Gambar Tim dan Masyarakat sedang melaksanakan IbM

3. Refleksi Hasil Penelitian

Selama proses pelatihan tim pelaksana kegiatan pengabdian melakukan pemantauan kepada para peserta pelatihan. Secara umum masyarakat terutama ibu-ibu mengatakan pelatihan ini sangat bermanfaat bagi mereka.

\section{KESIMPULAN}

Kegiatan pengabdian Ipteks bagi Masyarakat (IbM) yang telah dilakukan berupa pelatihan pemanfaatan limbah plastik menjadi barang bernilai ekonomi. Pelatihan diawali dengan mengenalkan jenis limbah plastik yang dapat diolah dan dijadikan barang yang bernilai ekonomi, kemudian dilanjutkan dengan cara pengolahan dan pemanfaatannya. Dari hasil diskusi dengan kepala Desa dan masyarakat sekitar selama pelaksanaan pengabdian, mereka sangat bersemangat dan berharap ada pelatihan-pelatihan selanjutnya. Kegiatan ini diharapkan tidak hanya dalam bentuk pengabdian saja, tetapi bisa dibentuk sebuah kerjasama terutama kepada ibu-ibu PKK.

\section{REFERENSI}

Marliani, Novi. 2014. Pemanfaatan Limbah Rumah Tangga (Sampah Anorganik) Sebagai Bentuk Implementasi dari Pendidikan Lingkungan Hidup. Jurnal Formatif 4(2): 124-132.

Nursruwening dkk. 2015. Pembuatan Handicraft Menggunakan Bahan Olahan Sampah Domestik. Prosiding SENATEK.

Pratiwi dkk. Sistem Pengelolaan Sampah Plastik Terintegrasi dengan Pendekatan Ergonomi Total Guna Meningkatkan Peran Serta Masyarakat (Studi kasus: Surabaya). Artikel.

Priyatna dkk. 2015. Perengkahan Lakalitik Limbah Plastik Jenis Polypropylene (PP) Menjadi Bahan Bakar Minyak Menggunakan Katalis Zeolita. JOM FTEKNIK 2(2).

Putra dkk. 2013. Pendampingan Kemitraan Pengelolaan Limbah Botol Plastik Menjadi Produk Bernilai Ekonomis pada Masyarakat Desa Girimoyo Karangploso Malang. Artikel.

Riswan dkk. 2011. Pengelolaan Sampah Rumah Tangga di Kecamatan Daha Selatan. Jurnal Ilmu Lingkungan 9(1): 31-38. 
Sofiana, Yunida. 2010. Pemanfaatan Limbah Plastik Sebagai Alternatif Bahan Pelapis (Upholster) pada Produk Interior. Jurnal INASEA 11(2): 96-102

Surono, Untoro Budi. 2010. Berbagai Metode Konversi Sampah Plastik Menjadi Bahan Bakar Minyak. 